\title{
Strategies and Treatments for Leafy Mistletoe (Phoradendron tomentosum (DC.) Engelm ex. Gray) Suppression on Cedar Elm (UImus crassifolia Nutt.)
}

\author{
W. Todd Watson and Tomas Martinez-Trinidad
}

\begin{abstract}
Leafy mistletoe, Phoradendron tomentosum (DC.) Engelm ex. Gray, can adversely affect trees growing in urban environments. The efficacy of several methods for controlling P. tomentosum in Ulmus crassifolia was evaluated in two separate trials. In the first experiment, eight treatments with five replicate trees, 20.3 to $30.5 \mathrm{~cm}$ (8.1 to $12.2 \mathrm{in}) \mathrm{dbh}$, were evaluated. Removal of the branch $30.5 \mathrm{~cm}$ (12.2 in) below the mistletoe, removal of mistletoe, and treating the branch bark with naphthaleneacetic acid (NAA) or a caulking compound in which mistletoe was removed resulted in reduced regrowth of the ectophyte (>90\%) after 5 months. The use of growth regulator and herbicides (ethephon, 2,4-D, and glyphosate) on intact mistletoe plants in experiment 1 did not provide acceptable control of mistletoe. After 29 months, only removal of the branch and caulking over the bark after mistletoe removal demonstrated a significant long-term effect on mistletoe mortality (40\% and 57\%, respectively). In the second experiment, a new treatment was evaluated based on the results from the first experiment. The use of NAA and light exclusion (black latex paint) reduced the resprouting of mistletoe by $50 \%$ after 8 months, but this effect diminished over time. However, 16 months after application, NAA and paint significantly reduced regrowth compared with removing mistletoe alone. This study provides strategies to achieve acceptable short-term control and long-term management of leafy mistletoe in urban trees.
\end{abstract}

Key Words. Auxin; Christmas mistletoe; herbicide; parasitic plant; pest.

Mistletoe is a parasitic plant that grows on conifer and hardwood trees in forest and urban environments around the world (Michailides et al. 1987; Lichter et al. 1991; Geils et al. 2002). Although mistletoe is photosynthetic, it is an obligate, semiparasitic evergreen plant that infects host plants to derive support, water, and essential elements (Scharpf and Hawksworth 1974; Coder 2004). In urban environments, they are considered a nuisance because of their appearance in deciduous trees during the winter. When colonization is extensive in individual trees, mistletoe can adversely affect tree health and cause decline and death of trees (Paine and Harrison 1992).

Phoradendron tomentosum (DC.) Englem. ex Gray, a leafy mistletoe species, primarily infests broad-leaved tree species such as hackberry, mesquite, oak, and elm in USDA zone 6 and warmer in the United States (Scharpf and Hawksworth 1974); however, it also commonly infests hickory, beech, poplar, walnut, pecans, cherry, and other tree species (Paine and Harrison 1992; Coder 2004; Wood and Reilly 2004). Although some mistletoe species show host specialization (Norton and Carpenter 1998), new sites (Melgar 2002) and new host species (Gilbertson and Mathiasen 2001) have been reported for broadleaf mistletoe. Therefore, studying control methods for mistletoe in urban forests is important as a result of the particular interactions of different tree species in several environments.

The primary mode of dispersion of mistletoe is by birds, which complicates the control of this parasitic plant. Birds deposit mistletoe seeds in a heterogeneous pattern creating a clumped distribution among hosts (Aukema and Martinez del Rio 2002). After seeds germinate, they produce an haustorium or root-like structures that penetrate the host to extract water and minerals (Paine and Harrison 1992). This endophytic portion results in a challenging control problem because treatments must kill the outer ectophytic portion of the plant as well as the endophytic portion without damaging the host. This is analogous to management of fungal diseases in plants.

Although the control of broadleaf mistletoe in urban forests can be difficult, several control methods have been tested, including branch removal, the use of ethylene, 2,4-D, glyphosate, shoot removal, and sunlight exclusion (Joyce et al. 1984, 1990; Lichter et al. 1991; Wood and Reilly 2004). Traditionally, arborists have controlled leafy mistletoe by using several different mechanical strategies. Mistletoe can be removed 
from the tree by pruning out the mistletoe shoots at the branch surface. Although the mistletoe might quickly resprout, some benefit is derived by annual mistletoe removal because it reduces seed production and spread of mistletoe within and among trees (Scharpf and Hawksworth 1974). Pruning of infected branches or covering affected areas with black plastic, paper, or aluminum foil has also been used with some success (Harris et al. 1999). These treatments work by prohibiting photosynthesis of the haustorium by opaque coverings. However, these treatments can be impractical in heavily infested trees as well as aesthetically objectionable.

Several growth regulators and herbicides have been tested that kill mistletoe shoots, but mistletoe can resprout from the haustoria several months after application (Lichter et al. 1991; Wood and Reilly 2004). Some of these chemicals such as dicamba also cause damage to the host (Wood and Reilly 2004). Ethephon, an ethylene-type compound, is currently labeled for control of mistletoe (Monterey Chemical Co., Fresno, CA), but this growth regulator has shown limited effectiveness at labeled rates (Adams et al. 1993). Auxin-type compounds such as 2,4-D have been effective, but it is unlikely that a product, which is primarily used as an herbicide, will ever be labeled for aerial spray applications in trees. Other auxin-type growth regulators such as 1-naphtaleneacetic acid, ethyl ester (NAA), that are labeled for control of sprouts and suckers in trees may provide useful control of leafy mistletoe in woody plants.

As a result of the lack of effective and practical means for controlling mistletoe, alternative methods for effectively controlling leafy mistletoe in urban environments need to be developed. The purpose of this article is to test the efficacy of several current and potential methods for controlling $P$. tomentosum in $U$. crassifolia.

\section{MATERIAL AND METHODS}

\section{Experiment 1}

Cedar elm trees infested with $P$. tomentosum served as hosts to evaluate the effect of different methods for controlling leafy mistletoe. In the first experiment in 2002, eight treatments were considered. Five replicate trees 20.3 to $30.5 \mathrm{~cm}$ (8.1 to 12.2 in) dbh per treatment were studied for a total of 40 trees. Within each tree, five mistletoe plants $(>20.3 \mathrm{~cm}$ [8.1 in] canopy spread diameter) were randomly selected within the canopies, resulting in 200 mistletoe test subjects. Remaining mistletoe plants were removed to avoid seeds dropping and sprouting into the test areas. The treatments consisted of removing mistletoe from the branch; removing mistletoe and branch to the nearest union ( $>30.5 \mathrm{~cm}$ [12.2 in] below the mistletoe); spraying mistletoe with a $5 \%$ ethephon solution ([2-chloroethyl] phosphonic acid) until runoff (Florel ${ }^{\circledR}$, Lawn and Garden Products, Fresno, CA); removing mistletoe and spraying with $1.15 \%$ solution of ethyl 1-naphthaleneacetic acid (Sucker Stopper Concentrate, Monterey
Chemical Co., Fresno, CA); spraying mistletoe with 2.5\% solution of iso-octyl (2-ethylhexyl) ester of 2,4-dichlorophenoxyacetic acid and isooctyl (2-ethylexyl) ester of 2-(2,4dichlorophenoxy propionic acid) solution (Brush Buster, Lawn and Garden Products, Fresno, CA); spraying mistletoe with $1.5 \%$ glyphosate solution (Roundup, Monsanto, MO); removing mistletoe and applying a latex based caulk NP-1 ${ }^{\mathrm{TM}}$ (Sonneborn, Shakopee, MN); and the controls. Spray and caulk treatments were applied to the mistletoe shoots and/or the bark to cover the entire branch out to $15.2 \mathrm{~cm}(6.1 \mathrm{in})$ on each side of the mistletoe.

Treatments were applied during the third and fourth week of February 2002 on dormant cedar elm trees located at the Texas A\&M University campus (College Station, TX). Treated trees were assessed on April 2002 and July 2002. Treated plants exhibiting more than $80 \%$ mortality were evaluated again on July 2004. During the first two evaluations, the mistletoe condition was scored based on visual assessment. The scale used during the assessment consisted of: $0=$ not present, $1=$ dead, $2=$ severely damaged, $3=$ curling, $4=$ yellowing, and $5=$ no apparent damage. Mistletoe regrowth was measured in July 2004.

\section{Experiment 2}

Dormant cedar elms similar to those used in experiment 1 were used. Based on the results from experiment 1, the efficacy of a modified treatment from experiment 1 was evaluated. To improve the results achieved with NAA in experiment 1, the treatments consisted of controls and a treatment to assess the efficacy of NAA mixed with black latex paint to would provide added benefit by excluding light from the haustorium. The evaluated chemical compound consisted of a mixture of $1.15 \%$ NAA (Sucker Stopper Concentrate, Monterey Chemical Co., Fresno, CA), black latex-based paint (Benjamin Moore \& Co., Montvale, NJ), and distilled water in a ratio 0.65:3.35:6.0, respectively. An average of $14.8 \mathrm{~mL}$ $(0.44 \mathrm{fl} \mathrm{oz})$ of the mixture was sprayed to cover the entire surface of the branch $15.2 \mathrm{~cm}$ (6.1 in) beyond either side of the cut mistletoe. The control treatment consisted of simply removing the mistletoe from the branch so that regrowth rates could be determined.

Treatments were applied during the first week of March 2003 using cedar elms located at the Texas A\&M University campus in College Station, Texas. The percentages of resprouted mistletoe were evaluated every month from April to July, in October 2003, and finally in July 2004. Mistletoe height was measured once during July 2004. The treatments were randomly assigned, and the data from both experiments were analyzed using SPSS. In the case of mortality, regrowth, and shoot length, the variables were transformed by adding 0.5 to the value and determining the square root. Mean comparisons were determined using LSD with a $P<0.05$. The condition values were analyzed using the Kruskal-Wallis test 
for determining significant differences among the treatments and the Wilcoxon test for determining significant differences $(P<0.05)$ of particular pairs of treatments.

\section{RESULTS AND DISCUSSION}

\section{Experiment 1}

None of the treatments resulted in visible short-term or longterm phytotoxicity to the host. Where the mistletoe was removed, all treatments (mistletoe removal, removal of the branch below the mistletoe, spraying the cut surface with NAA, or applying NP-1 to the branch) exhibited significantly higher mortality of the ectophyte at 5 months after treatment than other treatments in which the mistletoe was left intact (Figure 1A). These results mirrored other studies that demonstrated that mechanical controls (pruning out infested branches and light exclusion) can be highly effective at controlling mistletoe regrowth (Lichter et al. 1991). However, pruning may be impractical for heavily infested trees as a result of the negative impact on tree aesthetics (Paine and Harrison 1992), structure, or health. No prior studies have documented the impact of dark-colored caulking compounds to prevent photosynthesis of the haustoria. However, Lichter et al. (1991) observed similar results when using black plastic or pruning paint instead of caulk. Although caulking may be easier to maintain and may be aesthetically less obvious than black plastic, we found the treatment to be physically cumbersome and less uniform.

There are no prior studies that can be used for comparison in which NAA was used to control leafy mistletoe. However,
Wood and Reilly (2004) used an auxin-type compound, 2,4$\mathrm{D}$, on broadleaf mistletoe (Phoradendron flavescens) in pecan trees (Carya illinoinensis). They achieved 90\% and 100\% mortality and no resprouting 1 year after application with three applications of 2,4-D applied at concentrations of $0.23 \%$ and $1.01 \%$ per application. Although we achieved excellent shortterm results with NAA, we found 2,4-D to be ineffective. The difference in efficacy may be the result of formulation, timing, number of applications, or environmental factors. For example, Michailides et al. (1987) reported effective control 1 year after treatment when applying a mixture of 2,4-D and dicamba on leafy mistletoe, but only a $58 \%$ and $60 \%$ control after 1.5 years on white alder (Alnus rhombifolia) and Chinese hackberry (Celtis sinensis), respectively. Regardless, it is unlikely that 2,4-D will ever be labeled for mistletoe control because of environmental and regulation concerns.

Michailides et al. (1987) found that growth regulators can affect the growth rate of mistletoe for 1 year after application. We compared the condition of treated mistletoe that had not been removed (spraying ethephon, 2,4-D, or glyphosate). These growth regulators, applied at labeled rates to control mistletoe or broadleaf weeds, did not significantly affect the health or condition of the mistletoes (Figure 1B). In most cases, the mistletoe exhibited chlorotic leaves. These data are supported by other studies on mistletoe (Joyce et al. 1984; Lichter et al. 1991; Wood and Reilly 2004). Lichter et al. (1991) were unable to achieve acceptable results with glyphosate (5\%) when used against Phoradendron villosum on blue oak (Quercus douglasii) or P. macrophyllum on honeylocusts

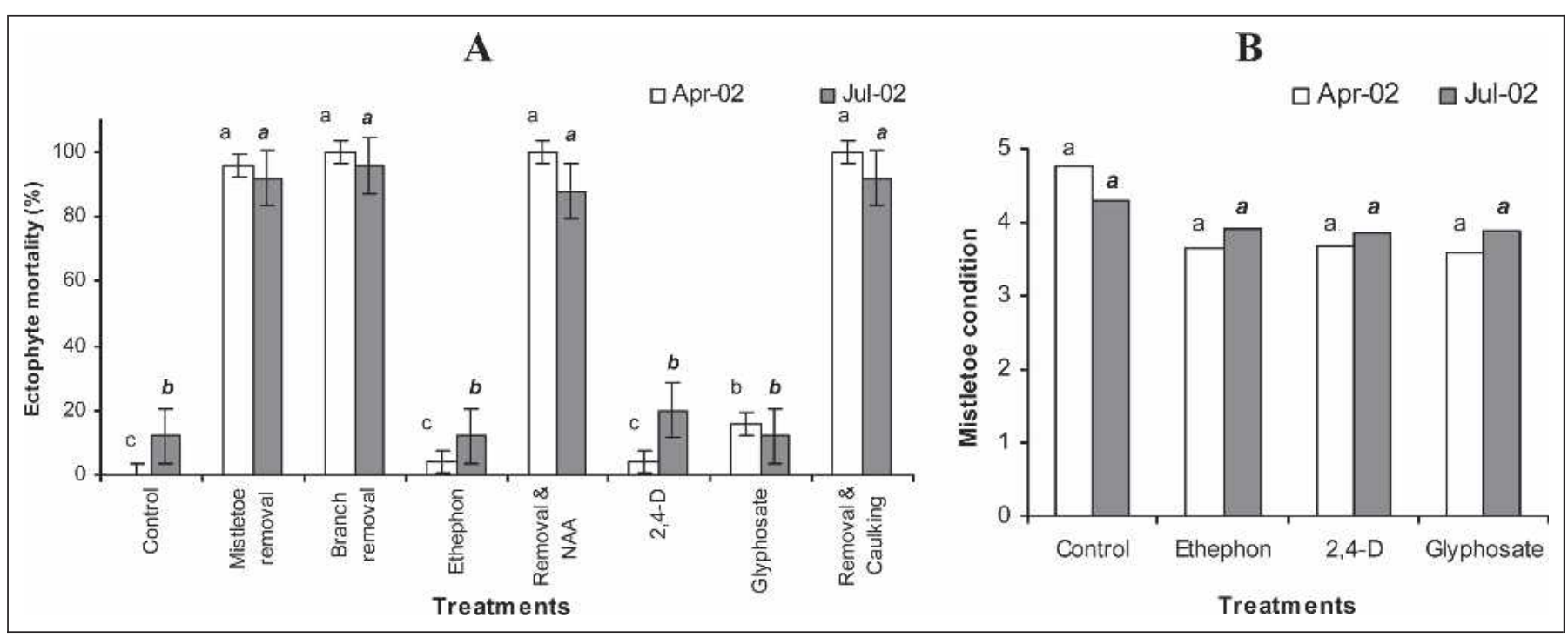

Figure 1. Ectophyte mortality (A) and condition (B) of $P$. tomentosum at 2 and 5 months after application of different control methods in experiment 1 on $U$. crassifolia at College Station, Texas $(0=$ not present, $1=$ dead, $2=$ severely damaged, 3 = curling, 4 = yellowing, 5 = no apparent damage). Mortality data showed without transformation. Different letters between treatments within the same date indicate significant differences $(P<0.05)$ using LSD after transformation for mortality and the Wilcoxon test for condition. 
(Gleditsia triacanthos f. inermis). Wood and Reilly (2004) found similar results when they evaluated glyphosate $(1.8 \%$ and $3.6 \%)$ as a means for controlling broadleaf mistletoe $(P$. flavescens) in pecan trees (C. illinoinensis). Although they achieved $80 \%$ and $100 \%$ mortality of shoots when applying ethephon at $0.18 \%$ and $1.6 \%$, respectively, they observed $100 \%$ regrowth of all mistletoe studied after 1 year.

In experiment 1 , although some of the treatments provided excellent short-term results, the efficacy of many of these treatments diminished over time (Figure 2). Resprouting from the haustoria was observed on mistletoe removal treatments at 29 months after application. Where caulking treatments were administered, resprouting occurred outside the caulk or within openings that occurred from misapplication or separation as a result of limb growth. Regrowth associated with NAA treatments occurred near the site of mistletoe removal. Because the entire branch was removed basipetally to the next branch union for the branch removal treatments, resprouting on the parent branch may have been the result of sprouting from introduced seed or resprouting from extensive haustoria. Aukema (2004) mentioned that the dispersion of mistletoe by birds follow a patch distribution that can provoke the reinfestation of the same tree. At the end of 29 months, only the branch removal and caulking treatments demonstrated a significant long-term effect on mistletoe mortality. As a result of the longevity of haustoria survival, future studies should involve long-term efficacy studies.

When assessing regrowth, ethephon, 2,4-D, glyphosate, and NAA exhibited regrowth that was not significantly different 29 months after application (Figure 3). Removing mistletoe, removing the branch, and caulking appeared to affect the final growth of mistletoe to a greater degree than

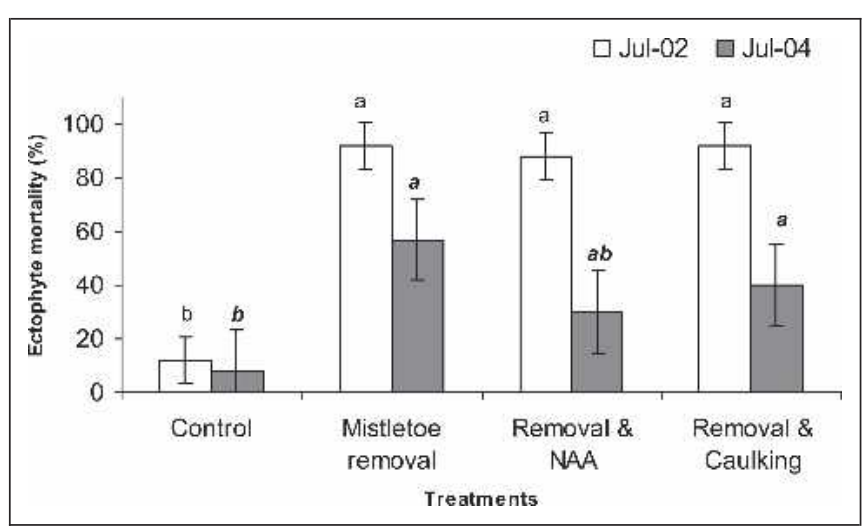

Figure 2. Ectophyte mortality (mean $\pm \mathrm{SE}$ ) of $P$. tomentosum for treatments in experiment 1 at 5 and 29 months after the application of control methods on $U$. crassifolia at College Station, Texas. Data showed without transformation. Different letters between treatments within the same date indicate significant differences $(P<0.05)$ using LSD after data transformation.

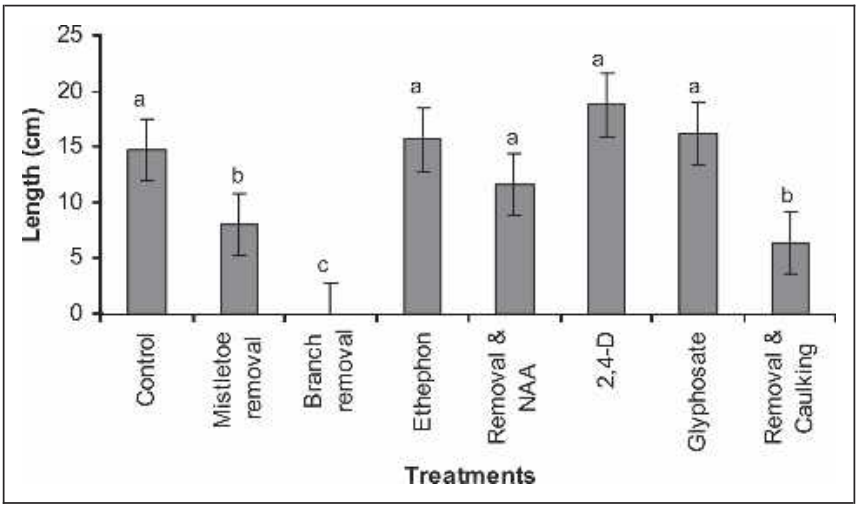

Figure 3. $P$. tomentosum growth (mean $\pm \mathrm{SE}$ ) 29 months after application in experiment 1 with 8 treatments on $U$. crassifolia at College Station, Texas. Data showed without transformation. Different letters between treatments indicate significant differences $(P<0.05)$ using LSD after data transformation.

other treatments, but only the branch removal treatment provided significantly better results than simply pruning out the mistletoe.

\section{Experiment 2}

Based on results from experiment 1 and Lichter et al. (1991), a second experiment was developed to explore long-term efficacy of combining a growth regulator (NAA) with a light exclusion compound (black pruning paint). The mixture significantly reduced resprouting of mistletoe by $50 \%$ after 8 months compared with $80 \%$ resprouting of mistletoe removal alone (Figure 4A). Unfortunately, the difference between the treatments was not significantly different at 16 months after treatment. As the affected branch increased in diameter over time, cracks developed in the paint that allowed light to penetrate to the bark. Resprouting occurred in these openings in the paint; however, mistletoe regrowth was significantly reduced even after 16 months (Figure 4B).

This and other studies (Joyce et al. 1984; Lichter et al. 1991; Wood and Reilly 2004) provide valuable evidence concerning the efficacy of some treatments to provide acceptable short-term and even long-term management of leafy mistletoe in urban trees. A variety of options now exist for providing levels of short-term control based on site conditions. The effect of short-term treatments on leafy mistletoe might decrease the damage cause by mistletoe infestation such as growth reduction, stress, and branch death (Coder 2004; Paine and Harrison 1992). These studies demonstrate that species, timing, control strategies, and concentrations affect success rate. More research is needed to continue to improve management options for controlling leafy mistletoe in urban environments. 


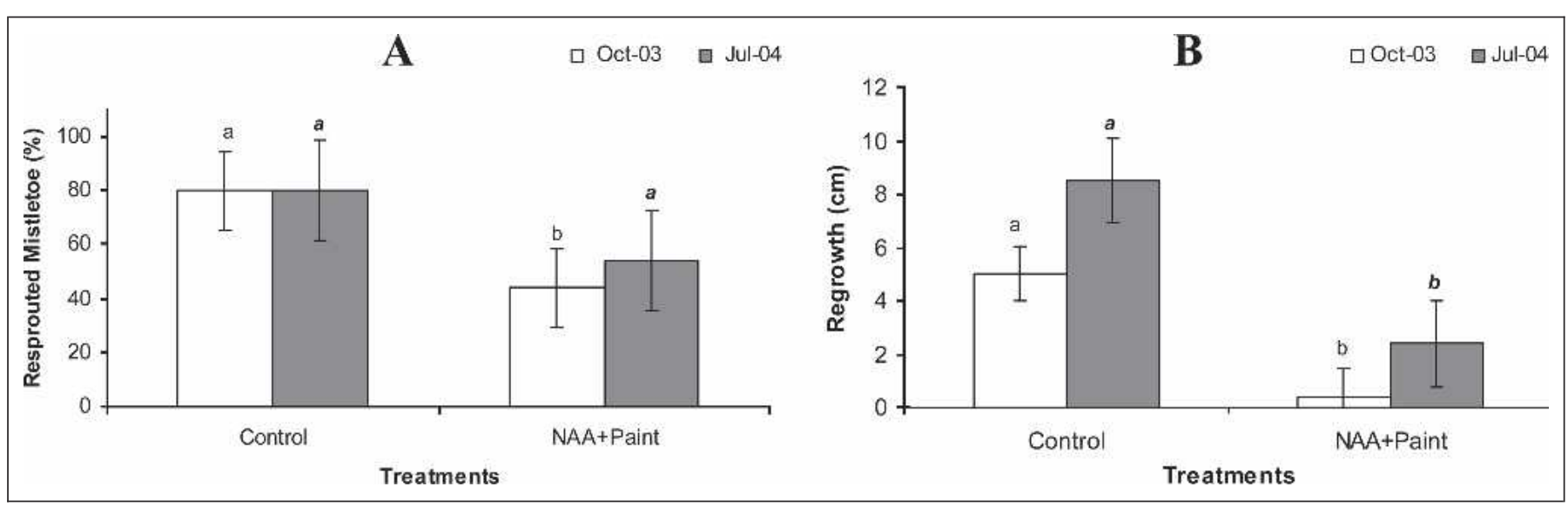

Figure 4. Percentage resprouting and regrowth (mean \pm SE) of $P$. tomentosum in experiment 2 at 8 and 16 months after mistletoe removal or mistletoe removal and an application of NAA and latex paint on $U$. crassifolia at College Station, Texas. Data showed without transformation. Different letters between treatments within the same date indicate significant differences $(P<0.05)$ using LSD after data transformation.

\section{IMPLICATIONS FOR ARBORICULTURE}

Leafy mistletoe is serious problem for urban trees in much of the United States and in other warmer regions of the world. Practicing arborists have tried several strategies to control this parasite, but there are few methods available that provide satisfactory results. With the availability of new compounds, alternative control strategies are now available that arborists can use to help control this unsightly pest. This article provides additional information about accepted control strategies and sheds light on some new alternatives that may be used to provide some control of this parasite as well as improve the health and appearance of trees.

Acknowledgments. The use of trade names in this publication does not imply endorsement by the authors or Texas A\&M University of the products named nor criticism of similar ones not mentioned. The authors acknowledge the technical assistance of the following Texas A\&M University collaborators: Dr. David N. Appel, Professor of Plant Pathology; Mr. Koby Weatherford, campus urban forester; Ms. Emily King, undergraduate student; and Mr. Jeff Lehde, graduate student.

\section{LITERATURE CITED}

Adams, D.H., S.J. Frankel, and J.M. Lichter. 1993. Considerations when using ethephon for suppression dwarf and leafy mistletoe infestations in ornamental landscapes. Journal of Arboriculture 19:351-357.

Aukema, J.E. 2004. Distribution and dispersal of desert mistletoe is scale-dependent, hierarchically nested. Ecography 27:137-144.

Aukema, J.E., and C. Martinez del Rio. 2002. Where does a fruit-eating bird deposit mistletoe seeds? Seed deposition patterns and an experiment. Ecology 83:3489-3496.

Coder, K.D. 2004. American mistletoe: Kissing under a parasite. Arborist News 13:37-44.
Geils, B.W., D. Wiens, and F.G. Hawksworth. 2002. Phoradendron in Mexico and the United States. USDA Forest Service Gen. Tech. Rep. RMRS-GTR-98.

Gilbertson, R., and R. Mathiasen. 2001. First report of Phoradendron macrophyllum on Populus tremuloides. Plant Disease 85:1120.

Harris, R.W., J.R. Clark, and N.P. Matheny. 1999. Arboriculture: Integrated Management of Landscape Trees, Shrubs, and Vines, 3rd ed. Prentice Hall, Upper Saddle River, NJ. 687 pp.

Joyce, D.C., M.S. Reid, and R.Y. Evans. 1990. Silver thiosulfate prevents ethylene induced abscission in holly and mistletoe. HortScience 25:90-92.

Joyce, D.C., K. Rein, A.M. Berry, and M.S. Reid. 1984. Control of broadleaf mistletoe (Phoradendron tomentosum) with dormant season ethephon sprays. Acta Horticulturae 201:141-144.

Lichter, J.M., M.S. Reid, and A.M. Berry. 1991. New methods for control of leafy mistletoe (Phoradendron spp.) on landscape trees. Journal of Arboriculture 17:127-130.

Melgar, J. 2002. First report of Phoradendron breedlovei in Honduras. Plant Disease 86:440.

Michailides, T.J., J.M. Ogawa, and S. Yoshimine. 1987. Survey for and chemical control of leafy mistletoe (Phoradendron tomentosum subsp. marcophyllum) on shade trees in Davis, California. Plant Disease 71:533-536.

Norton, D.A., and M.A. Carpenter. 1998. Mistletoes as parasites: Host specificity and speciation. Trends in Ecology \& Evolution 13:101-105.

Paine, L.K., and H.C. Harrison. 1992. Mistletoe: Its role in horticulture and human life. HortTechnology 2:324-330.

Scharpf, R.F., and F.G. Hawksworth. 1974. Mistletoes on Hardwoods in the United States. USDA. Forest Service, 
Pacific Southwest Research Extension. Forest Pest leaflet 147.

Wood, B.W., and C.C. Reilly. 2004. Control of mistletoe in pecan trees. HortScience 39:110-114.

\author{
W. Todd Watson (corresponding author) \\ Assistant Professor of Urban and Community Forestry \\ Department of Forest Science \\ Texas A\&M University \\ College Station, TX 77843-2135, U.S. \\ t-watson@tamu.edu
}

\section{Tomas Martinez-Trinidad \\ PhD Student \\ Department of Forest Science \\ Texas A\&M University \\ College Station, TX 77843-2135, U.S.}

Résumé. Le balai de sorcière causé par Phoradendron tomentosum (DC.) Engelm ex. Gray peut affecter négativement les arbres en milieu urbain. L'efficacité de plusieurs méthodes pour contrôler $P$. tomentosum chez Ulmus crassifolia a été évaluée sur deux groupes séparés d'essais. Dans la première expérience, huit traitements sur cinq répliquent d'arbres de 20,3 à 30,5 cm de DHP ont été évalués. L'enlèvement de la branche à $30,5 \mathrm{~cm}$ sous le balai de sorcière, l'enlèvement simple du balai de sorcière, ainsi que le traitement de l'écorce de la branche avec de l'acide naptalène-acétique ou l'application d'une pâte la où le balai de sorcière a été enlevé a permis d'obtenir une réduction de repousse de l'ectophyte cinq mois plus tard (>90\%). L'emploi de régulateurs de croissances et d'herbicides (ethephon, 2,4-D, glyphosate) sur les balais de sorcières intacts dans l'expérience no 1 n'a pas permis d'obtenir un contrôle acceptable du balai de sorcière. Après 29 mois, seul l'enlèvement de la branche et l'application d'un enduit sur l'écorce après l'enlèvement du balai de sorcière a démontré un effet significatif à long terme sur le taux de mortalité du balai de sorcière (40 et $57 \%$ respectivement). Dans la seconde expérience, un nouveau traitement a été évalué en se basant sur les résultats de la première expérience. L'emploi d'acide naphtalène-acétique et l'application d'une couche de peinture au latex noire pour bloquer le passage de la lumière a permis de réduire les rejets de balais de sorcière par $50 \%$ après huit mois, mais cet effet diminuait avec le temps. Néanmoins, 16 mois après l'application d'acide naphtalène-acétique et de peinture noire au latex, cela a permis une réduction des rejets comparativement à l'enlèvement seul du balai de sorcière. Cette étude fournit des stratégies pour atteindre un niveau de contrôle acceptable du balai de sorcière à court et long terme chez les arbres urbains.
Zusammenfassung. Die Mistel Phoradendron tomentosum (DC.) Engelm ex. Gray kann Bäume im urbanen Umfeld in ihrem Wachstum beeinflussen. In zwei separaten Versuchen wurde die Effektivität von verschiedenen Methoden der Mistelkontrolle bewertet. Im ersten Experiment wurden 8 Behandlungen mit fünf Bäumen (Brustdurchmesser 20,3 cm-30,5 cm) bewertet. Eine Entfernung von dem Ast $30 \mathrm{~cm}$ unter der Mistel, Entfernung der Mistel und Behandlung der Astrinde mit NAA oder einem abdichtenden Material, wo die Mistel gesessen hat, führte zu einem reduzierten Nachwachsen des Ektophyten (>90\%) nach 5 Monaten. Der Einsatz von Wachstumsregulatoren und Herbiziden bei gesunden Misteln im ersten Experiment führte nicht zu einem akzeptablen Ergebnis. Nach 29 Monaten zeigten nur die Entfernung des betroffenen Astes und die Abdichtung Mistelansatzstelle nach der Mistelentfernung einen deutlichen Langzeiteffekt auf die Lebensdauer der Mistel (40\%, resp. 57\%). Im zweiten Experiment wurde eine neue Behandlung bewertet auf der Basis des ersten Experiments. Der Einsatz von NAA und Lichtausschluss (schwarze Latexfarbe) reduzierten den Wiederaustrieb von Misteln um 50\% nach 8 Monaten, aber dieser Effekt nahm über die Zeit ab. Trotzdem reduzierten die Applikation von NAA und die schwarze Farbe den Wiederaustrieb deutlicher als der alleinige Rückschnitt von Misteln. Diese Studie liefert Strategien, um kurzfristige Kontrollen und langfristiges Management von Mistelbewuchs in der Stadt zu erhalten.

Resumen. El muérdago, Phoradendron tomentosum (DC.) Engelm ex. Gray, puede afectar adversamente a los árboles que crecen en ambientes urbanos. Se evaluó la eficacia de varios métodos para controlar P. tomentosum en Ulmus crassifolia en dos ensayos separados. En el primer experimento, se evaluaron ocho tratamientos con cinco repeticiones de árboles de $20.3-30.5 \mathrm{~cm}$. (8-12 pulg) de DAP. La remoción de la rama a $30.5 \mathrm{~cm}$. (12 pulg) debajo del muérdago, la remoción del muérdago, y tratando a la corteza de la rama con ácido naftaleneacético (NAA) o un compuesto sellador donde el muérdago fue removido, resultó en rebrotes reducidos (>90) después de cinco meses. El uso del regulador del crecimiento y herbicidas (etefon, 2,4-D y glyfosate) sobre las plantas de muérdago intactas, en el Experimento 1, no proporcionaron un control aceptable del muérdago. Después de 29 meses, solamente la remoción de la rama y sellando sobre la corteza después de la remoción del muérdago demostró un efecto significativo a largo plazo sobre la mortalidad del muérdago (40 y 57\% respectivamente). En el segundo experimento, se evaluó un nuevo tratamiento basado en los resultados del primero. El uso de NAA y la exclusión de la luz (pintura negra de látex) redujeron el rebrote del muérdago por un $50 \%$ después de ocho meses, pero este efecto disminuyó sobre el tiempo. Sin embargo, dieciséis meses después de la aplicación de NAA y pintura, se redujeron significativamente los rebrotes, comparando con la remoción del muérdago solamente. Este estudio proporciona estrategias para lograr un control aceptable a corto plazo y manejo a largo plazo del muérdago en árboles urbanos. 